\title{
DIGITALISATION AND PLATFORM ECONOMY - DISRUPTION IN SERVICE SECTOR
}

\author{
Jakosuo, Katri
}

Future Academy

2019

Jakosuo , K 2019 , DIGITALISATION AND PLATFORM ECONOMY - DISRUPTION IN SERVICE SECTOR . in M Ozsahin \& T Hidirlar (eds), JOINT CONFERENCE ISMC 2018-ICLTIBM 2018 - 14TH INTERNATIONAL STRATEGIC MANAGEMENT CONFERENCE 8TH INTERNATIONAL CONFERENCE ON LEADERSHIP, TECHNOLOGY, INNOVATION AND BUSINESS MANAGEMENT . European Proceedings of Social and Behavioural Sciences, vol. 54 , Future Academy, Nicosia , pp. 75-85, Joint Conference of 14th International Strategic Management Conference (ISMC) and 8th International Conference on Leadership, Technology, Innovation and Business (ICLTIBM), Prague , Czech Republic , 12/07/2018 . https://doi.org/10.15405/epsbs.2019.01.02.7

http://hdl.handle.net/10138/323322

https://doi.org/10.15405/epsbs.2019.01.02.7

cc_by_nc_nd

publishedVersion

Downloaded from Helda, University of Helsinki institutional repository.

This is an electronic reprint of the original article.

This reprint may differ from the original in pagination and typographic detail.

Please cite the original version. 


\title{
Joint Conference: $14^{\text {th }}$ ISMC and $8^{\text {th }}$ ICLTIBM-2018 DIGITALISATION AND PLATFORM ECONOMY - DISRUPTION IN SERVICE SECTOR
}

\author{
Katri Jakosuo (a)* \\ *Corresponding Author
}

(a) University of Helsinki, Department of Economics and Management, Consumer Economics, University of Helsinki, katri.jakosuo@ gmail.com

\begin{abstract}
Digitalisation and the platform economy have changed business and consumption patterns. Similarly, ways of working have also changed and become polarised as a result of automation, robots, e-commerce and blockchains bringing new innovations to the markets and changing earnings logic. Lower and middle-class jobs decrease or disappear, and high skilled roles increase. The new digital innovations and the progressive expansion of large platforms, such as Airbnb and Uber, have also placed pressure on the development of legislation, globally. The purpose of this study is to describe how digitalisation and the platform economy affect the service sector in general and how this disruption has implications for service sector companies, blue-collar workers and consumers. This research is based on qualitative content analysis. According to the results, digitalisation and the platform economy have both positive and negative effects. For example, these phenomena are expanding business markets and increasing the choice of consumers and the freedom of employees. On the other hand, the insecurity of employees and competition between local and global companies may increase uncontrollably.
\end{abstract}

(C) 2019 Published by Future Academy www.FutureAcademy.org.uk

Keywords: Digitalisation, disruption, platform economy, polarisation of work, sharing economy. 


\section{Introduction}

The service sector is changing rapidly with digitalisation and the platform economy. ${ }^{1}$ The changes have been enormous, especially in the retail sector. In 1982, the Boston Computer Exchange launched one of the first e-commerce marketplace platforms for selling used computers (Mamis, 1991). It is remarkable to consider that in less than four decades the e-commerce market would be a global phenomenon and would grow enormously. According to the Statista (2018), in 2017 retail e-commerce sales worldwide amounted to $\$ 2.3$ trillion and e-retail revenues are projected to grow to $\$ 4.88$ trillion in 2021 . The sharing economy is estimated to grow from $\$ 14$ billion in 2014 to $\$ 335$ billion by 2025 (PwC, 2015), and World Economic Forum (2016) has forecast that 65 percent of children entering primary school today will ultimately end up working in completely new job types that, as yet, do not exist.

The changes have also affected other service sectors other than merely the retail sector. For example, Airbnb, Uber and Wolt have changed accommodation, transportation and restaurant services and business logic considerably. At the same time, consumer behaviour and working life have changed significantly. Digitalisation has redefined value chains and placed the consumer at the centre (EY 2017).

From the perspective of companies, employees and consumers, the discussion of digitalisation and the platform economy is often too theoretical and quite confusing because it is difficult to understand the significance and magnitude of the effects. In addition, it is difficult to perceive the whole, because often these changes are only discussed from the perspective of a single actor - even though phenomena are affecting all the above-mentioned actors at the same time.

The purpose of this study is to describe how digitalisation and the platform economy affect the service sector in general and how this disruption is reflected in service sector companies, blue-collar workers and consumers.

\section{Literature Review and Theoretical Framework}

From a technical point of view, digitisation is the process that converts information from a physical format into a digital format. A number of disruptive technologies have already changed the manufacturing sector, production, productivity and quality. For example, big data/open data has significantly reduced costs of computation, the Internet of Things (IoT, M2M) has reduced cost of connectivity and cloud computing has helped centralize the data (Schmidt \& Cohen 2013; McKinsey, 2015a, 11). However, digitalisation does not just concern technical issues because the phenomenon also changes our behaviour and integrates different digital technologies into business and everyday life.

Megatrends, such as globalisation and standardisation, have a significant impact on technical development and, through that, business operations and people's daily lives. In the service sector digitisation involves many phenomena such as automation, robots, platforms and self-service (Figure 1). These phenomena are different, but the connecting factor is that they would not be possible without digitalisation. At the same time, they allow different forms of co-operation between business and machines (B2M) or between businesses and consumers (B2C). (McKinsey \& Company 2015b; Jakosuo, 2017a.)

\footnotetext{
${ }^{1}$ The platform economy is also called, for example, collaborative economy, sharing economy or gig economy (Kilhoffer et al. 2017).
} 


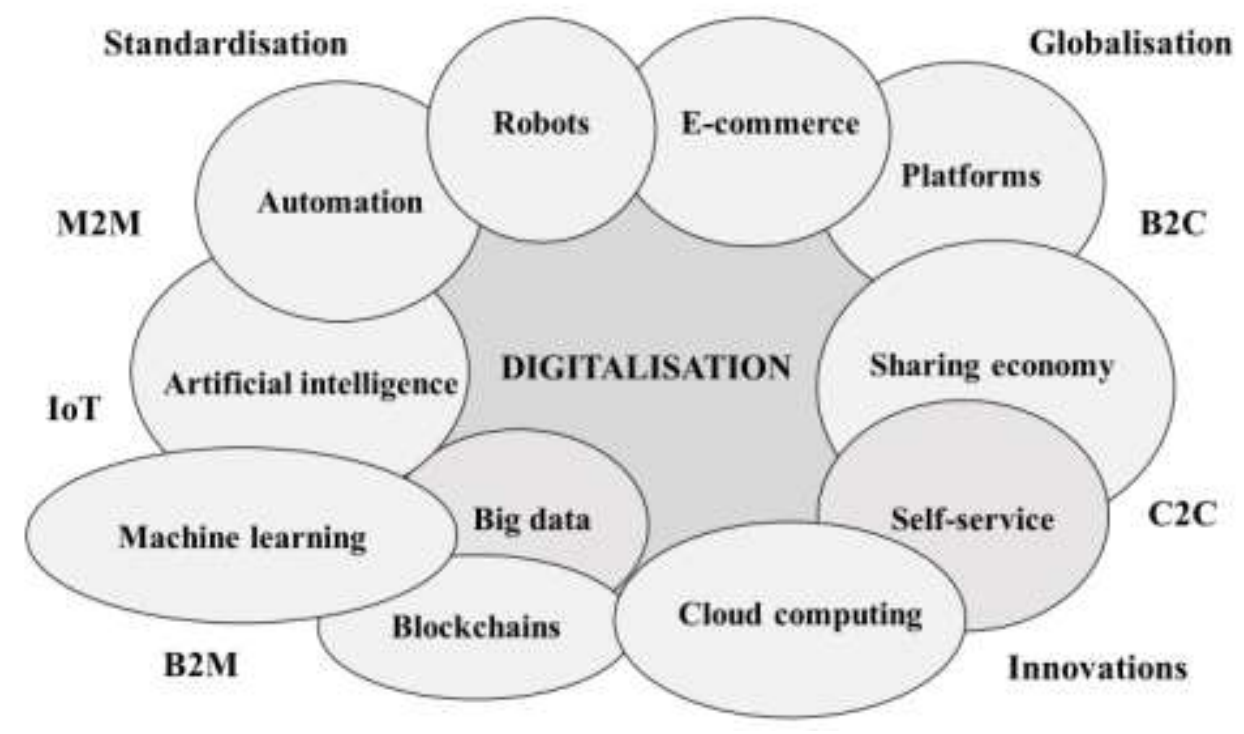

Figure 01. Digitalisation as Phenomena (Jakosuo 2017a)

The sharing and platform economy is a new economic sector where different companies provide the technological platforms for the operators who can be other companies, communities or individuals. Through these platforms the operators can create, for example, new services that produce added value. The platforms can be divided into two different categories - the platforms that relay rentals such as Airbnb and Uber and the platforms that relay the buying and selling of private services like Upwork (Farrell \& Greig 2016). Remarkably, even though some platforms are part of the sharing economy, many platforms are not.

The platform economy includes many heterogeneous services with different configurations of relationships between users, businesses and service providers. Globally the most famous examples are Airbnb, a platform which enables people to rent their own homes for short-term rental, and Uber, a platform in which a car owner can offer a taxi service. In addition to Airbnb and Uber, there are several platforms such as the American platform Upwork, which is a global freelancing platform for companies and independent professionals. Others include the following: Weclean, a Norwegian a private home cleaning platform; Worksome, a Danish platform for academic work; Lingjob, a Lithuanian platform; and the Latvian Academy of Ideas. The platforms have also created new consumption innovations, for example, online C2C markets for used goods (e.g. www.tori.fi).

According to Frenkena and Schorb (2017), the full economic effects of a sharing economy are complex. The rise of sharing economy markets will have indirect effects on other markets. For example, legacy businesses and their workers in related markets are likely to experience lower earnings. In some cases, the hotel earnings have been shown to decline in places where Airbnb has grown. Analyses have shown that the impacts were uneven across the industry: Airbnb has become a partial substitute for hotel stays, especially in the cheaper segments of the hotel market. Airbnb has also raised rents in Rovaniemi, which is a very popular tourist destination in Finnish Lapland (Koskela, 2018).

Although there is great interest in the sharing and platform economy, it appears to be very difficult to find any statistics or evidence of the impact of the sharing and platform economy on the total economy 
in different countries. In any case, from the point of view of income, the sharing and platform economy seem to be a bigger phenomenon in Europe than in America. Farrell and Greig (2016) have estimated that about one percent of Americans adults have received revenue from a digital platform. Contrastingly, in Europe, several surveys indicate that up to 10-15 percent of the European population earn money through digital platforms (Huws, Spencer, \& Joyce, 2016). The European surveys have also found that earnings through platforms are limited and only a very small number of persons get their main income from it. According to the studies only 4 percent of Britons got their main income on platforms and only 0,3 percent of Finnish earned some income on platforms in 2017 (Eurofound, 2017; Tilastokeskus, 2018).

\section{Data and Methods}

This research is based on qualitative content analysis, which is useful for studying a limited number of cases in depth and it provides individual case information. Also, a qualitative approach is well suited for understanding phenomena within their context, uncovering links among different effects. Despite this, qualitative research has several drawbacks, like subjectivity. The data can never be perfect, because the researcher selects the data and makes choices between different sources. In addition, the amount of data is typically smaller than in a quantitative analysis, for which reason qualitative data only provides a snapshot view of the phenomenon. The data are used to describe, rather than explain, the phenomenon (Patton, 2002; Yin 2003; Anttila, 2006).

The analyses and the findings are based on textual data, like journals, working papers and surveys. The study is limited to observing only those effects which are related to digitalisation and platform economy in service sector and changes that affect consumers, companies and the work of blue-collar workers in the service sector. A summary of the textual data is shown on Table 1.

Table 01. A Summary of the Textual Data

\begin{tabular}{|l|l|l|}
\hline Type of Reference & Themes & Author(s) \\
\hline Journal & $\begin{array}{l}\text { Consumer behaviour, digital } \\
\text { services, platform economy } \\
\text { and polarisation of work. }\end{array}$ & $\begin{array}{l}\text { Eroğlu 2014, Foroudi et al. 2018, Leimeister } \\
\text { Österle, \& Alter, 2014, Wiefel 2015, } \\
\text { Yordanova 2015 }\end{array}$ \\
\hline Working Paper & $\begin{array}{l}\text { Digitalisation in service } \\
\text { sector, future of work and } \\
\text { polarisation of work. }\end{array}$ & $\begin{array}{l}\text { Degryse, 2016, Valenduc \& Vendramin 2016, } \\
\text { Eurofound, 2017, EY, 2017, Jakosuo, 2017a; } \\
\text { 2017b, 2018, VZBV 2017, Kilhoffer, et al. } \\
2017\end{array}$ \\
\hline Survey or Interview & $\begin{array}{l}\text { Consumer behaviour, } \\
\text { digitalisation in service sector, } \\
\text { future of work and e- } \\
\text { commerce. }\end{array}$ & EK, 2017, Kurjenoja, 2017, PostNord, 2018 \\
\hline
\end{tabular}

In this research, the textual data is considered in the light of content analysis. According to Silverman (1997), the content analysis is an accepted method of textual investigation. The method involves establishing categories and then counting the number of instances in which those categories are used in a particular item of text. 


\section{Findings}

\subsection{Companies: From local markets to global competition}

Digitalisation has already changed the service market and service production significantly. Digitalisation and digital channels lower barriers to entry and increase globalisation and competition (e.g. EY 2017). For example, many new innovations and actors have come to traditional service sectors. At the same time, ways of working have changed: warehouse work has shifted from raising heavy boxes to automated warehouse systems and queuing in the local shops has changed to self-service, global ecommerce and automatic cash machines (Table 2).

Table 02. Digitalisation in Service Sector - Changes and Examples (Jakosuo 2017a; 2018)

\begin{tabular}{|c|c|c|c|}
\hline \multirow{2}{*}{ Sector } & \multirow{2}{*}{ Competitive advantage } & \multicolumn{2}{|l|}{ Examples } \\
\hline & & Digitalisation & In practice \\
\hline Retail and wholesale & $\begin{array}{l}\text { a lot of choice, fast } \\
\text { delivery, global markets, } \\
\text { customisation }\end{array}$ & $\begin{array}{l}\text { self-service, e- } \\
\text { commerce, } \\
\text { automation, robots }\end{array}$ & $\begin{array}{l}\text { automatic cash machines, } \\
\text { smartcarts, automated } \\
\text { warehouse systems }\end{array}$ \\
\hline $\begin{array}{l}\text { Hotels, catering and } \\
\text { tourism }\end{array}$ & $\begin{array}{l}\text { locality, experiences, } \\
\text { customer service, shorter } \\
\text { waiting times }\end{array}$ & $\begin{array}{l}\text { mobile apps, } \\
\text { tablets, delivery } \\
\text { platforms }\end{array}$ & $\begin{array}{l}\text { self-checkout, in-room } \\
\text { tablets, on-demand meal } \\
\text { ordering }\end{array}$ \\
\hline $\begin{array}{l}\text { Property and } \\
\text { facilities }\end{array}$ & $\begin{array}{l}\text { functionality, safety, } \\
24 / 7 \text {, customisation }\end{array}$ & $\begin{array}{l}\text { automation, robots, } \\
\text { drones, 3D, 4D, 5D, } \\
6 \mathrm{D}\end{array}$ & $\begin{array}{l}\text { roof inspections with } \\
\text { thermal imaging camera, } \\
\text { security drone systems }\end{array}$ \\
\hline
\end{tabular}

In the digital era, knowledge is power. Product management, information on the best-selling products, the allocation of products, the speed of delivery for end-users and information on the total cost of supply chains will give companies a competitive advantage. Moreover, the physical location of a product is irrelevant because the logistics chains operate around the world. For example, 80 percent of Nordic online shoppers consider that being able to choose the method of delivery when shopping online is important (EY, 2017; PostNord, 2018; Weise, 2018). Amazon has also understood that one key indicator is the delivery time from the customer's order to the end-user: depending upon a customer's delivery address and the location of the item ordered, customer can choose same-day delivery instead of one-day or two-day delivery. Amazon has also launched a free two-hour delivery of Whole Foods products in four American cities (Amazon, 2018).

Digitalisation has also changed business logic. Nowadays, many new platforms provide direct competition to the traditional operators. For traditional operators this means that they need to change their procedures, such as their opening hours, product range and cost-effectiveness. In Finland, this phenomenon has even led to the bankruptcies of the traditional big retail chains (e.g. the department store chains Anttila, the retail store chain Tiimari and the clothing chain Seppälä) (Oksanen, 2017). Digitalisation allows also that workers and tasks in the platform economy can be located in different countries. For example, several Nordic telemarketing firms are seeking to save money by setting up in Spain, where wages and living costs 
are lower than in Scandinavia. Typically, these companies hire, for example, Finnish or Swedish young people and pay them lower wages than they would in the home country.

Digitalisation can also transform traditional market structures. For example, the ability of producers and manufacturers to sell their products directly to consumers has the potential to break up the current market structure in food retail. Farmers and producers of niche products are increasingly establishing direct links with their customers, bypassing the traditional food retailers completely in some cases. They can offer their products online and thereby create a more diverse offering and greater choice for consumers. (VZBV, 2017)

The new digital economy involves both local and global aspects. For example, Uber operates in the local market, where the buyer (customer) and seller (the owner and the rider of car) often live in the same city or even in the same district. On the other hand, the digitalisation enables different cross-border activities - the buyer and seller of the service can be situated in widely different countries and time zones. At the same time, digitalisation increases competition between local and global companies and may cause social dumping (e.g. moving production to lower-wage countries or the employment of cheaper labour from lower-wage countries).

\subsection{Employees: Disruption and polarisation}

Digitalisation is not a new phenomenon, but its extent and speed has surprised many. Digitisation enables the automation of work either in part or in full, and it can also increase freedom and occupational safety. Innovation, such as blockchains and artificial intelligence, can also replace part of routine tasks in the future. However, changes in work patterns can also increase dissatisfaction (e.g. monotonous tasks and few social contacts) and generate feelings of uncertainty.

The digitalisation of work requires a good standard of ICT-proficiency from employees. However, good skills are not self-evident. According to the OECD (2017), there is already polarisation between different groups. Demand in both high-skilled and low skilled occupations is rising, and demand for medium-skilled intermediate occupations is falling. One significant problem is that low skilled employees cannot obtain the education they need. The other problem is that many companies hold the opinion that employees should be responsible for their own training (EK, 2017). However, the training and education of employees is also important in the digital era (Valenduc \& Vendramin, 2016). Indeed, without training and skilled workers companies may lose the benefits of automation and digitalisation (e.g. costeffectiveness can be reduced if employees are not able to operate robotic technologies).

The platform economy and platform work lead to changes in the nature of work and may cause confusion. Often the position of platform workers is not considered to be particularly desirable. ${ }^{2}$ Even though many of them work voluntarily on the platforms and have the freedom to choose their work, the wage and job security maybe low and there are no predictable and regular working hours (Eurofound, 2017; Kilhoffer, et al. 2017). In the sharing and platform economy, it is also very common that customer satisfaction has an impact on job opportunities and wage. This may be very stressful and affect well-being at work (Valenduc \& Vendramin, 2016). An additional problem is that many employers hire independent

${ }^{2}$ The platform workers are also called crowd workers or gig workers (Kilhoffer et al. 2017). 
self-employed workers to evade employment law obligations. For self-employed workers, this could significantly undermine their social security benefits and entitlements (e.g. no holiday pay or sick pay).

The risk is that polarisation and growing inequality between highly skilled and low-skilled workers, between men and women, young and old, home country and immigrant workers may increase in the future (Degryse, 2016). On the other hand, especially in low-income countries, digitalisation and platform work can offer better working conditions, in terms of wages and a balance between work and private life (Yordanova, 2015).

\subsection{Consumers: More information, choices - and power}

Digitalisation has a significant impact on consumers' shopping habits. E-commerce and different platforms have become important actors in the retail market for consumer goods and services. New innovations have eliminated geographical limitations and ensured that consumers receive information more easily and in much less time and with lower costs. In addition to price comparisons, consumers have the possibility to discuss products or services with other consumers or even with a firm representative on online consumer communities' platforms. Consumers have become more powerful in retail markets - especially since the competitors and different alternatives are just one click away (Eroğlu, 2014; Leimeister, et al. 2014).

Consumers' expectations and personalization have also risen, and many consumers are expecting greater convenience and also multi-channels from the traditional stores, such as time saving, fast delivery and assistance with decision-making. Uniquely customized shopping experiences are also increasingly important. (Eroğlu, 2014; Wiefel, 2015) Likewise, self-service has increased in various services, such as online banking and retail shops providing automatic cash machines. (Jakosuo, 2017a; Kurjenoja, 2017.) On the other hand, digitalisation may also increase inequality if services are designed for only smartphone users (Foroudi, et al. 2018).

New innovations (e.g. platforms and e-commerce) make it easier for consumers to be in direct contact with producers. This is one reason why direct selling and direct deliveries are increasing (VZBV, 2017). In addition, the price transparency is increasing as consumers can compare the prices of products and services and they have real-time access to competitive pricing information. For example, access to lower prices and a broader ranges of goods entices many Nordic consumers to buy from other countries (PostNord, 2018).

Digitalisation also involves considerable challenges. One such example is related services where there is a third party between the company and the customers (e.g. Aliexpress, Airbnb and Wolt). In these cases, the role of the customer is often blurred. Sometimes it is difficult to define who the customer actually is within the process or who holds the responsibility. For instance, when ordering a meal via delivery service, it may be difficult to pinpoint whether the customer within the food on demand process is the consumer who orders the meal via the delivery service, or the restaurant that prepares the food. 


\subsection{Summary: Digitalisation and Platform Economy in Service Sector}

Digital technologies have transformed the traditional business. This disruption has not only changed the lives of companies, but also the lives of employees and consumers. (EY, 2017; Wiefel, 2015) Table 3 summarizes the different phenomena and effects of digitisation in the service sector from the viewpoints of companies, blue-collar workers and consumers.

Table 03. Phenomena and Effects of Digitalisation on the Service Sector (Jakosuo, 2017a; 2017b; 2018)

\begin{tabular}{|c|c|c|c|c|c|}
\hline & $\begin{array}{l}\text { Automation } \\
\text { and robots }\end{array}$ & Blockchains & Platforms & E-commerce & Self-Service \\
\hline Companies & $\begin{array}{l}\text { Increase } \\
\text { productivity and } \\
\text { predictability of } \\
\text { quality, reduced } \\
\text { direct labour costs, } \\
\text { high initial cost, } \\
\text { possible security } \\
\text { threats (e.g. Cyber- } \\
\text { attacks) }\end{array}$ & $\begin{array}{l}\text { User-controlled } \\
\text { networks, more } \\
\text { transparency, } \\
\text { reduced } \\
\text { transaction costs, } \\
\text { can replace part of } \\
\text { the routine work } \\
\text { (e.g. Making } \\
\text { agreements) }\end{array}$ & $\begin{array}{l}\text { Opportunities to } \\
\text { micro business, } \\
\text { smes and niche } \\
\text { markets, decrease } \\
\text { power of traditional } \\
\text { operators, may } \\
\text { polarize the } \\
\text { markets and reduce } \\
\text { fair competition }\end{array}$ & $\begin{array}{l}\text { New business } \\
\text { opportunities: } \\
\text { from local market } \\
\text { to global markets, } \\
\text { time- and place- } \\
\text { independent } \\
\text { markets: potential } \\
24 / 7 \text { income, lot } \\
\text { of competitors }\end{array}$ & $\begin{array}{l}\text { Cost-effectiveness, } \\
\text { opportunities for } \\
\text { personalisation, } \\
\text { may attract } \\
\text { customers who } \\
\text { want efficiency } \\
\text { (e.g. Shorter } \\
\text { waiting times) }\end{array}$ \\
\hline Employees & $\begin{array}{l}\text { Work can be } \\
\text { automated either in } \\
\text { part or in full, } \\
\text { occupational safety } \\
\text { may increase, may } \\
\text { reduce the social } \\
\text { interaction }\end{array}$ & $\begin{array}{l}\text { Work tasks can be } \\
\text { disappeared, } \\
\text { verifying and } \\
\text { assessing the } \\
\text { education, skills } \\
\text { and performance } \\
\text { of employees }\end{array}$ & $\begin{array}{l}\text { Freedom to choose } \\
\text { work, but } \\
\text { insecurity may } \\
\text { increase, wage may } \\
\text { be low, customer } \\
\text { satisfaction may } \\
\text { have an impact on } \\
\text { job opportunities }\end{array}$ & $\begin{array}{l}\text { May increase } \\
\text { polarisation, tasks } \\
\text { may be monotonic } \\
\text { and cause health } \\
\text { problems (e.g. } \\
\text { Ergonomics } \\
\text { problems and } \\
\text { stress) }\end{array}$ & $\begin{array}{l}\text { Work may } \\
\text { disappear, lack of } \\
\text { personal touch, } \\
\text { may increase } \\
\text { polarisation (e.g. } \\
\text { Services } \\
\text { concentrate in big } \\
\text { cities) }\end{array}$ \\
\hline Consumers & $\begin{array}{l}\text { Increases } \\
\text { information and } \\
\text { access to } \\
\text { information (e.g. } \\
\text { More detailed } \\
\text { product } \\
\text { information) }\end{array}$ & $\begin{array}{l}\text { Digital footprints } \\
\text { increase } \\
\text { confidence and } \\
\text { transparency, } \\
\text { better supply } \\
\text { chain visibility } \\
\text { (e.g. Ability to } \\
\text { trace raw } \\
\text { materials) }\end{array}$ & $\begin{array}{l}\text { More new products } \\
\text { and services, may } \\
\text { increase } \\
\text { polarisation } \\
\text { between different } \\
\text { consumer groups, } \\
\text { and problems with } \\
\text { privacy and } \\
\text { security }\end{array}$ & $\begin{array}{l}\text { Reduce traditional } \\
\text { shopping (e.g. } \\
\text { Shops and stores), } \\
\text { better } \\
\text { opportunities to } \\
\text { compare prices }\end{array}$ & $\begin{array}{l}\text { Enables faster } \\
\text { service and shorter } \\
\text { waiting times, less } \\
\text { personal and face } \\
\text { to face service }\end{array}$ \\
\hline $\begin{array}{l}\text { Practical } \\
\text { Examples }\end{array}$ & $\begin{array}{l}\text { American Amazon's } \\
\text { dynamic warehouse } \\
\text { network, } \\
\text { Honda's humanoid } \\
\text { robot ASIMO }\end{array}$ & $\begin{array}{l}\text { Estonians national } \\
\text { health records, } \\
\text { Ethereum smart } \\
\text { contracts (e.g. for } \\
\text { real estate) }\end{array}$ & $\begin{array}{l}\text { Chinese AliExpress } \\
\text { e-commerce, } \\
\text { Cloud-based e- } \\
\text { procurement } \\
\text { platforms for } \\
\text { public sector }\end{array}$ & $\begin{array}{l}\text { German e- } \\
\text { commerce } \\
\text { Zalando, B2B } \\
\text { e-Commerce, like } \\
\text { Bright Agrotech }\end{array}$ & $\begin{array}{l}\text { Finnish intelligent } \\
\text { shopping cart } \\
\text { solutions, } \\
\text { Scandit mobile } \\
\text { self-checkout app }\end{array}$ \\
\hline
\end{tabular}

Digitalisation is a technological, psychological, disruptive and transformational process. Developments in digitalisation, automation and robotics mean that many blue-collar works are being automated either in part or in full. Despite this, it seems that human skills and understanding of user and customer behaviour and needs are becoming even more critical in the digital world and sustainable competitive advantage is probably to depend on human capacity. From a management point of view, leadership changes, but it will not disappear (e.g. ability to lead organization's transformation, ability to lead non-traditional platform work and ability to gain competitive advantage by implementing artificial intelligence). 


\section{Conclusion and Discussions}

The purpose of this study is to describe how digitalisation and the platform economy affect the service sector in general and how this disruption is reflected in service sector companies, blue-collar workers and consumers. The empirical findings add to the existing literature by highlighting for instance the relationships between customer knowledge management and a competitive advantage and the strong relationships between customer feedback and platform workers' job opportunities and wage. Furthermore, an interesting research implication is that this study points out that the digitalisation can led to the bankruptcies of the traditional national retail chains.

The literature review and the qualitative analysis also showed that the digitalisation and the rise of the sharing and platform economy has changed the service sector and industrial relations across all countries. Despite this, the regulation of the sharing and platform economy is globally still very limited and, therefore, there are many grey areas within the sharing and platform economy. For example, it is difficult to identify whether their activity is professional or whether it is merely to earn extra income (e.g. Airbnb). In addition, it is sometimes also difficult to determine who is the real customer - and who has the ultimate responsibility.

Depending on countries and services, the sharing and platform economy can increase the risk of unfair competition. For example, if the transport sector is strictly regulated (e.g. limited numbers of taxi licenses in a certain region), Uber can confuse these taxi markets. This has led to varying approaches towards Uber, depending on the country (CJEU, 2017). Nowadays there are countries with regional bans, a country-wide partial ban and a country-wide full ban. This complex situation shows that different regions in the same country can react differently to innovations and new services.

In the best cases, the innovations and new services make the markets more efficient and increase consumers' choice whilst lowering price levels - but in the worst cases they change the earnings logic and make the whole industry unprofitable in the long term. In addition, digitalisation requires a greater human and user perspective. Involving employees in the decision-making process and the continuous dialogue with employees concerning their digital training needs and digital user experiences are keys to employee engagement and business success.

The study of digitalisation and platform economy in service sector provides a basis for several interesting further research. First, from a managerial perspective the digitisation has already changed business models. For example, different networks and subcontracting have become an increasingly important. It is clear that we cannot halt progress. Therefore, we need a broader discussion and more research of the benefits of digitisation and how it should be controlled local and global (e.g. regulatory, technical and ethical standards).

Second, the strategic management literature emphasized a sustainable competitive advantage and the importance of continuing development. Companies must create clear goals, strategies and operations to build sustainable competitive advantage. The values of the employees and corporate culture must be in alignment with those goals. (Porter 1985; Kaplan \& Norton 2004). The big questions are how companies can increase non-traditional workers' commitment and how, for example, platform workers can take part in 
the in-house innovation processes. Especially when the non-traditional work and the number of crowd workers have been growing.

Finally, the platform economy places a strong emphasis on customers' experiences and customer feedback (e.g. Uber and Airbnb). The problem is that measuring customer satisfaction does not always tell how to achieve it. Another problem is that these inquiries can be unreliable because they are generic, automatically created and not all customers or users respond to the inquiries. Linking pay to customer feedback surveys can lead to gaming the system, anger, finger-pointing and defensiveness, rather than to a focus on better customer experience (Markey, 2011). Customers' and users' ideas can be used as a source of inspiration and innovation to develop the current business, but one significant ethical issue is that can the platform workers' wage only be based on customer feedback and customer satisfaction?

\section{References}

Anttila, P. (2006). Tutkiva toiminta ja ilmaisu, teos, tekeminen, Akatiimi, Hamina, Finland.

Amazon. (2018). Shipping Rates \& Times, Retrieved 26 March 2018 from https://amzn.to/2K8Dm4G.

CJEU. (2017). The service provided by Uber connecting individuals with non-professional drivers is covered by services in the field of transport, Court of Justice of the European Union Press Release $136 / 2017$

Degryse, C. (2016). Digitalisation of the economy and its impact on labour markets, European Trade Union Institute Working Papers.

EK. (2017). Henkilöstön osaamistarpeet digitaloudessa, Elinkeinoelämän Keskusliiton henkilöstö- ja koulutustiedustelu 3/2017.

Eroğlu, E. (2014). The Changing Shopping Culture: Internet Consumer Behavior, Review of Business Information Systems 18 (1), 35-40.

Eurofound (2017). Future of Work: Making It e-Easy', Background paper for Estonian Presidency Conference 'Future of Work: Making It e-Easy' 13-14 September 2017.

EY. (2017). Disruption. Digitalization. Disintermediation. Transportation and logistics in the coming decade, Ernst \& Young LLP.

Farrell, D., \& Greig, F. (2016). Paychecks, Paydays, and the Online Platform Economy - Big Data on Income Volatility, JPMorgan Chase Institute.

Foroudi, P., Gupta, S., Sivarajah, U., \& Broderick, A. (2018). Investigating the effects of smart technology on customer dynamics and customer experience, Computers in Human Behavior 2018 (80), 271282.

Frenkena, K., \& Schorb, J. (2017). Putting the sharing economy into perspective, Environmental Innovation and Societal Transitions 2017 (23), 3-10.

Huws, U., Spencer, N. H., \& Joyce, S. (2016). Crowd Work in Europe. Preliminary results from a survey in the UK, Sweden, Germany, Austria and the Netherlands, University of Hertfordshire, Feps Studies.

Jakosuo, K. (2017a). Digitalisaatio palvelualoilla, Muistio Palvelualojen ammattiliiton sisäiseen käyttöön. Jakosuo, K. (2017b). Työn murros, Palvelualojen ammattiliiton lausunto eduskunnan Tulevaisuusvaliokunnalle 15 November 2017.

Jakosuo, K. (2018). Digitalisaatio matkailualalla, Muistio Palvelualojen ammattiliiton sisäiseen käyttöön. Kaplan, R. S., \& Norton, D. P. (2004). Strategy Maps, Harvard Business School Press, Boston, Massachusetts, USA.

Kilhoffer, Z., Lenaerts, K., \& Beblavý, M. (2017). The Platform Economy and Industrial Relations: Applying the old framework to the new reality, Centre for European Policy Studies Research Report $2 / 2017$.

Koskela, T. (2018). Airbnb haastaa opiskelijakaupungin asuntomarkkinat. Lapin ylioppilaslehti 2018 (1), $18-21$ 
Kurjenoja, J. (2017). Kaupan digitalisaatio nyt-Asiakkaat ovat digimaailmassa, onko kauppa?, Kaupan liitto.

Leimeister, J. M., Österle, H., \& Alter, S. (2014). Digital services for consumers, Electron Markets 2014 (24), 255-258.

Mamis, R. A. (1991). The Used-Computer Market - A computer exchange brings used computer buyers and sellers together, INC.com.

Markey, R. (2011). The Dangers of Linking Pay to Customer Feedback, Harvard Business Review 8 September 2011.

McKinsey \& Company. (2015a). Industry 4.0 - How to navigate digitization of the manufacturing sector, McKinsey Digital.

McKinsey \& Company. (2015b). Finnish service sector growth and the impact of the digitalization, In: TEM. 2015. Service Economy Revolution and Digitalisation - Finland's Growth Potential, The Ministry of Employment and the Economy, Innovation 41/2015, 45-67.

OECD. (2017).OECD Employment Outlook 2017, Organisation for Economic Co-operation and Development.

Oksanen, J. (2017). Tiimari, Anttila, Erätukku, Seppälä... - Jatkuuko syöksykierre? Retrieved 26 March 2018 from https://www.is.fi/taloussanomat/art-2000005334542.html.

Patton, M. Q. (2002), Qualitative research and evaluation methods, 3rd edition, SAGE Publications, Thousand Oaks, USA.

Porter, M. (1985). The Competitive Advantage: Creating and Sustaining Superior Performance, Free Press, NY, USA.

PostNord. (2018), The Nordics - A digitized region: A review of Nordic residents' online purchasing behavior, E-commerce in the Nordics 2017 report.

PwC. (2015). The Sharing Economy, PricewaterhouseCoopers Consumer Intelligence Series.

Silverman, D. (1997). Interpreting Qualitative Data, SAGE, London, Great-Britain.

Statista. (2018). Retail e-commerce sales worldwide from 2014 to 2021, Retrieved 28 March 2018 from https://www.statista.com/statistics/379046/worldwide-retail-e-commerce-sales.

Schmidt, E., \& Cohen, J. (2013). The New Digital Age: Reshaping the Future of People, Nations and Business, John Murray Publishers, London, Great-Britain.

Tilastokeskus. (2018). Noin 0,3 prosenttia suomalaisista sai vähintään neljäsosan ansioistaan digitaalisten alustojen kautta vuonna 2017, Statistics Finland's Press Release 17 April 2018.

Valenduc, G., \& Vendramin, P. (2016). Work in the digital economy: Sorting the old from the new, European Trade Union Institute Working Paper 3/2016.

VZBV. (2017). The Digitalisation of Food. VZBV's positions, Verbraucherzentrale Bundesverband e.V. Federation of German Consumer Organisations.

Weise, E. (2018). Amazon starts free, 2-hour Whole Foods deliveries in fresh test of grocery model, Retrieved 15 April 2018 from https://eu.usatoday.com/story/tech/news/2018/02/07/amazonlaunches-whole-foods-deliveries-four-cities/318337002/

Wiefel, M. (2015). Digitalization: The impact on traditional retail and the future model of multichannel, International Journal of Scientific and Research Publications 5 (3), 1-9.

World Economic Forum (2016). The Future of Jobs: Employment, Skills and Workforce Strategy for the Fourth Industrial Revolution. World Economic Forum.

Yin, R.K. (2003). Case study research: Design and methods, 3rd edition, SAGE Publications, Thousand Oaks, USA.

Yordanova, G. (2015). Global Digital Workplace as an Opportunity for Bulgarian Woman to Achieve Work-Family Balance, COST Action IS 1202, The Dynamics of Virtual Work, Working Paper Series 5 . 